\title{
Evaluation of test-day milk somatic cell count information to predict intramammary infection with major pathogens in dairy cattle at drying off
}

\author{
Z. Lipkens, S. Piepers, A. De Visscher, and S. De Vliegher* \\ M-team \& Mastitis and Milk Quality Research Unit, Department of Reproduction, Obstetrics and Herd Health, Faculty of Veterinary Medicine, \\ Ghent University, 9820 Merelbeke, Belgium
}

\section{ABSTRACT}

The objectives of this study were (1) to determine the test characteristics and predictive values of cowlevel milk somatic cell count (SCC) information from (multiple) test-day recordings before drying off to identify major-pathogen-infected cows at drying off; and (2) to explore to what extent (an estimate of) the herd prevalence of subclinical mastitis, milk yield level, and parity of the cows affects the estimates. In total, 550 cows from 15 commercial dairy herds with overall good udder health management were dried-off during a study period of 6 mo. Test-day SCC were available through milk recording and within $5 \mathrm{~d}$ before drying off cows were sampled for quarter-level bacteriological culturing serving as the gold standard. Sensitivity (Se), specificity $(\mathrm{Sp})$, positive predictive value (PPV), and negative predictive value (NPV) were calculated at different threshold values of SCC, ranging between 50,000 and 500,000 cells $/ \mathrm{mL}$, to detect major-pathogen-infected cows. At a commonly used threshold of 200,000 cells/ $\mathrm{mL}$, the Se and Sp of (a combination of) test-day SCC before drying off ranged between 37.6 and $57.6 \%$ and between 66.7 and $79.3 \%$, respectively. Still, estimates were modified by the herd level prevalence of subclinical mastitis and the cow's milk yield and parity. For instance, at the 200,000 cells $/ \mathrm{mL}$ threshold using the geometric mean SCC of the 3 last test-days, the overall Se, Sp, PPV, and NPV were 37.6, 79.3, 30.8, and $83.9 \%$, respectively, whereas these were $27.8,87.5$, 21.7 , and $90.6 \%$, respectively, for heifers and $40.3,73.5$, 33.3 , and $78.9 \%$, respectively, for multiparous cows. In conclusion, test-day SCC records obtained via milk recording are reliable to detect dairy cows at drying off that are not infected with major pathogens as determined by bacteriological culture and could eventually facilitate implementation of selective dry cow therapy in commercial dairy herds. Because estimates of the

Received September 4, 2018.

Accepted January 9, 2019.

*Corresponding author: Sarne.Devliegher@UGent.be herd-level prevalence of subclinical mastitis, milk yield level, and parity of the cows affect the estimates of the test characteristics and predictive values to some extent, one should consider taking these parameters into account when differentiating infected from uninfected cows based on SCC data.

Key words: drying off, test characteristics, predictive values, somatic cell count data

\section{INTRODUCTION}

Subclinical mastitis continues to be one of the most expensive diseases for the dairy sector because it greatly affects milk production and quality (Halasa et al., 2007). To detect IMI, bacteriological culture of milk samples remains the gold standard (Hogan et al., 1999), also at drying off. Yet, due to practical and financial constraints, it is not often used. The California mastitis test is a cheap and quick alternative that has been used to detect major-pathogen-infected cows, also at drying off (Poutrel and Rainard, 1981), but it lacks accuracy. More promising in that respect is an on-farm culture system such as the Petrifilm (Cameron et al., 2013), although this method requires time, sufficient expertise (e.g., a large enough herd), and specific material. The use of SCC as a proxy for a cow's udder health (i.e., to differentiate between infected and uninfected cows using a specific threshold) has been used in many countries for years, and is also part of DHI programs (e.g., Laevens et al., 1997; Barrett et al., 2006; Madouasse et al., 2010) providing cow-level SCC data on a regular basis. Recently, the test characteristics and predictive values of composite SCC information obtained via DHI recordings throughout lactation were estimated to distinguish major-pathogen-infected lactating cows from noninfected and minor-pathogen-infected lactating cows. At a threshold of 200,000 cells/mL, a sensitivity (Se), specificity (Sp), positive predictive value (PPV), and negative predictive value (NPV) of 65.1, 73.0, 40.6 , and $88.1 \%$, respectively, were reported (Jashari et al., 2016). Whether test-day SCC information available before drying off can be used to accurately identify 
major-pathogen-infected cows at drying off remains to be determined.

Still, last test-day SCC information before drying off (e.g., Scherpenzeel et al., 2014; Vanhoudt et al., 2018) was used as the main selection criterion to implement selective dry cow therapy (SDCT), whereas combining the SCC information from several DHI records before drying off seems promising (Torres et al., 2008). The authors also suggested considering herd characteristics such as herd IMI prevalence because this will likely affect the test efficacy and predictive values. Still, whether the cow's parity and milk yield levels besides the herd prevalence of subclinical mastitis also affect the Se, Sp, PPV, and NPV when predicting the IMI status at drying off, as they do in lactation (Jashari et al., 2016), remains to be studied.

The objectives of this study were (1) to determine the test characteristics and predictive values of cow-level milk SCC information based on (multiple) test-day recordings before drying off to differentiate between uninfected/minor-pathogen-infected cows and majorpathogen-infected cows at drying off, using bacteriological culture as the gold standard, and (2) to explore to what extent (an estimate of) the herd prevalence of subclinical mastitis, milk yield level, and parity of the cows affects the estimates.

\section{MATERIALS AND METHODS}

\section{Enrollment of Herds and Animals}

In total, 15 dairy herds milking 1,363 Holstein Friesian cows were enrolled. All herds participated in the local DHI program of the cooperative cattle improvement organization (CRV, Sint-Denijs-Westrem, Belgium) on a 4- to 6 -wk basis. The herds were required to have an overall good udder health management, as reflected by a geometric mean bulk milk SCC (BMSCC) $\leq 250,000$ cells/mL (Schukken et al., 1992) for a period of 6 mo before enrollment in the study (for calculation, see below). All herds had a conventional milking parlor (tandem, $\mathrm{n}=5$; herringbone, $\mathrm{n}=5$; side-by-side, $\mathrm{n}=$ 4 ; carousel, $\mathrm{n}=1$ ). The average number of lactating cows per herd was 91 (ranging from 48 to 215) and the average 305-d milk production was $8,839 \mathrm{~kg}$ (ranging from 5,922 to $11,594 \mathrm{~kg}$ ) on the last DHI record before the start of the sampling period (i.e., when drying off the first cow per herd). The geometric mean BMSCC of April 2015 (i.e., start of the sampling period) was calculated based on the available BMSCC records of the month of April (4 to 8 measurements per herd) and revealed a minimum, maximum, and average of $73,000,317,000$, and 175,000 cells $/ \mathrm{mL}$, respectively. All producers applied blanket dry cow therapy and cows calved year-round. For practical reasons, a minimum of about 50 lactating cows per herd was applied as an inclusion criterion as well as being situated within a 50$\mathrm{km}$ radius around the Faculty of Veterinary Medicine of Ghent University (Merelbeke, Belgium).

Between April and December 2015, 582 cows were dried-off, of which 32 were excluded from the data set due to incomplete data (see further), resulting in 550 cows available for analyses.

\section{Samplings}

The last 3 DHI records before drying off per cow were captured in a database, including the SCC values (SCC DHI-3, SCC DHI-2, and SCC DHI-1, respectively, as compared with the day of drying off; cows being at 256, 293, and 330 DIM, respectively). Within a maximum of $5 \mathrm{~d}$ before drying off, all cows were sampled by the first author. Before milking, after discarding the first streams of milk and after disinfection of the teats, single quarter milk samples (volume: $5 \mathrm{~mL}$ ) were collected for culturing. At all times, milk samples were transported and stored under cooled conditions $\left(4^{\circ} \mathrm{C}\right)$. Within $24 \mathrm{~h}$ after sampling, bacteriological culturing was performed on the aseptically collected quarter milk samples. In case bacteriological culturing was not feasible within $24 \mathrm{~h}$ after sampling, milk samples were frozen at $-18^{\circ} \mathrm{C}$ awaiting further analyses for periods up to $1 \mathrm{wk}$. Although it is known that freezing can affect the recovery of certain bacteria (Hubáčková and Ryšánek, 2007), due to the limited freezing period and the limited number of samples that were frozen, this effect, if any, was minimal.

Twenty-five cows did not have a DHI record available that provided last test-day SCC before drying off, whereas 7 cows were not sampled $(\mathrm{n}=5)$ for culturing, or were sampled too early (i.e., $>5 \mathrm{~d}$ before drying off, $\mathrm{n}=2$ ).

\section{Laboratory Analyses}

Bacteriological Culturing. Culturing was performed as prescribed by National Mastitis Council guidelines (Hogan et al., 1999). From each quarter sample, $10 \mu \mathrm{L}$ of milk was inoculated on a quadrant of a blood-esculin (Oxoïd, Aalst, België) and a MacConkey agar (Oxoïd). After an aerobic incubation period of 24 and $48 \mathrm{~h}$ at $37^{\circ} \mathrm{C}$, phenotypically different colonies were counted and identified using Gram staining and inspection of the colony morphology. Catalase tests were performed to differentiate staphylococci (grampositive and catalase-positive) and streptococci (gram- 
positive and catalase-negative). DNase tests, colony morphology, hemolysis patterns, and coagulase tests were used to distinguish Staphylococcus aureus and non-aureus staphylococci. Streptococci were subdivided into esculin-positive streptococci (Streptococcus uberis and other esculin-positive streptococci) and esculinenegative streptococci (Streptococcus agalactiae and Streptococcus dysgalactiae) based on the appearance on blood-esculin agar, bile-esculin agar (Oxoid), and a Christie, Atkins, and Munch-Petersen test. Corynebacterium spp. were differentiated from the catalasepositive staphylococci by Gram staining. Trueperella pyogenes was distinguished from the catalase-negative streptococci based on growth, hemolysis patterns, and Gram staining. Bacillus spp., fungi, and yeast were identified based on colony morphology and Gram staining.

The samples were considered to show significant growth if $\geq 3$ colonies $(\geq 300 \mathrm{cfu} / \mathrm{mL})$ were observed of a phenotypically similar colony type (Pantoja et al., 2009), and the samples were considered to be contaminated in case $\geq 3$ phenotypically different colony types were observed (Pantoja et al., 2009), with the exception of non-aureus staphylococci as phenotypically different colony types were allowed because different colony types can belong to the same species (De Visscher et al., 2013).

Somatic Cell Counting. The SCC DHI-1, SCC DHI-2, and SCC DHI-3 were determined by Fossomatic 5000 Electronic Cell Counter (MCC Flanders, Lier, Belgium).

\section{Herd- and Cow-Level Strata}

Monthly BMSCC data (at least 4 measurements per month) were available per herd (MCC Flanders). The geometric mean SCC of all BMSCC measurements per herd (i.e., 4 to 8 measurements per month) was calculated over a period of 6 mo before enrollment. Herds were stratified into so-called low-prevalence herds (LP herds) and high-prevalence herds (HP herds), referring to the likely prevalence of subclinical mastitis, based on the median BMSCC value, which was 157,000 cells $/ \mathrm{mL}$ (interquartile range of 107,000 to 181,000 cells $/ \mathrm{mL}$ )], resulting in $7 \mathrm{LP}$ herds $(<157,000$ cells $/ \mathrm{mL})$ with 248 cows and $8 \mathrm{HP}$ herds $(\geq 157,000$ cells $/ \mathrm{mL})$ with 302 cows.

Cows were stratified as so-called low-yielding cows $(<20 \mathrm{~kg} ; \mathbf{L Y}, \mathrm{n}=260)$ and so-called high-yielding cows $(\geq 20 \mathrm{~kg} ; \mathbf{H Y}, \mathrm{n}=290)$ based on the average milk yield at DHI-1 [average $19.90 \mathrm{~kg}$ (interquartile range of $16.0 \mathrm{~kg}$ to $23.0 \mathrm{~kg}$ )] and were stratified based on their parity at DHI-1 into heifers (parity $1, \mathrm{n}=201$ ) and multiparous cows (parity $\geq 2, \mathrm{n}=349$ ).

\section{Intramammary Infection Status}

The IMI status of the cows was based on the quarterlevel bacteriological results (Table 1), in the following hierarchic order: (1) the IMI status of a cow was considered undefined if $\geq 1$ of the quarter milk samples was contaminated or infected with fungi or yeast; (2) a cow was considered to be infected with (a) major pathogen(s) if $\geq 1$ quarter milk sample(s) showed significant growth of Staphylococcus aureus, Streptococcus dysgalactiae, Streptococcus agalactiae, Streptococcus uberis, esculin-positive streptococci other than Streptococcus uberis, Trueperella pyogenes, or gram-negative bacteria and not if the quarter milk samples was contaminated or infected with fungi or yeast; (3) a cow was considered to be infected with (a) minor pathogen(s) if $\geq 1$ quarter milk sample(s) showed significant growth of Corynebacterium spp. or non-aureus staphylococci and none of the quarters was infected with (a) major pathogen(s), and none of the quarter milk samples was contaminated or showed significant growth of fungi or yeast; and (4) only in case that all quarter milk samples were culture-negative or showed nonsignificant growth of any pathogen (including Bacillus spp.), the cow was considered to be uninfected. Nineteen cows (3.5\%) had one blind quarter at sampling, the IMI status of these cows was based on 3 instead of 4 quarter-level bacteriological results.

\section{Data Sets}

As mentioned before, 550 cows were available for this study. Two subsets of data were prepared:

(1) Data set SCC DHI-1: includes data from 441 cows, defined as uninfected, minor pathogen infected, and major pathogen infected at drying off, used for the assessment of the diagnostic properties of SCC DHI-1 at given thresholds (see further in Diagnostic Properties). The last DHI record (DHI-1) was collected at on average 330 DIM.

(2) Data set SCC DHI-123: includes data from 433 cows, defined as uninfected, minor pathogen infected, and major pathogen infected at drying off, of which SCC DHI-1, SCC DHI-2, and SCC DHI-3 were available. This subset of data was used for the assessment of the diagnostic properties of (1) geoSCC DHI-123 and of (2) sumSCC DHI-123, when at given thresholds a combination of SCC before drying off obtained via DHI recording were taken into account (see below in Diagnostic Properties). The third last (DHI-3), second last (DHI-2), and last DHI record (DHI- 
Table 1. Prevalence and distribution of mastitis pathogens isolated from 550 cows and 2,200 quarters from 15 dairy herds in Flanders at drying off (data set SCC DHI-1), and associated cow-level IMI status

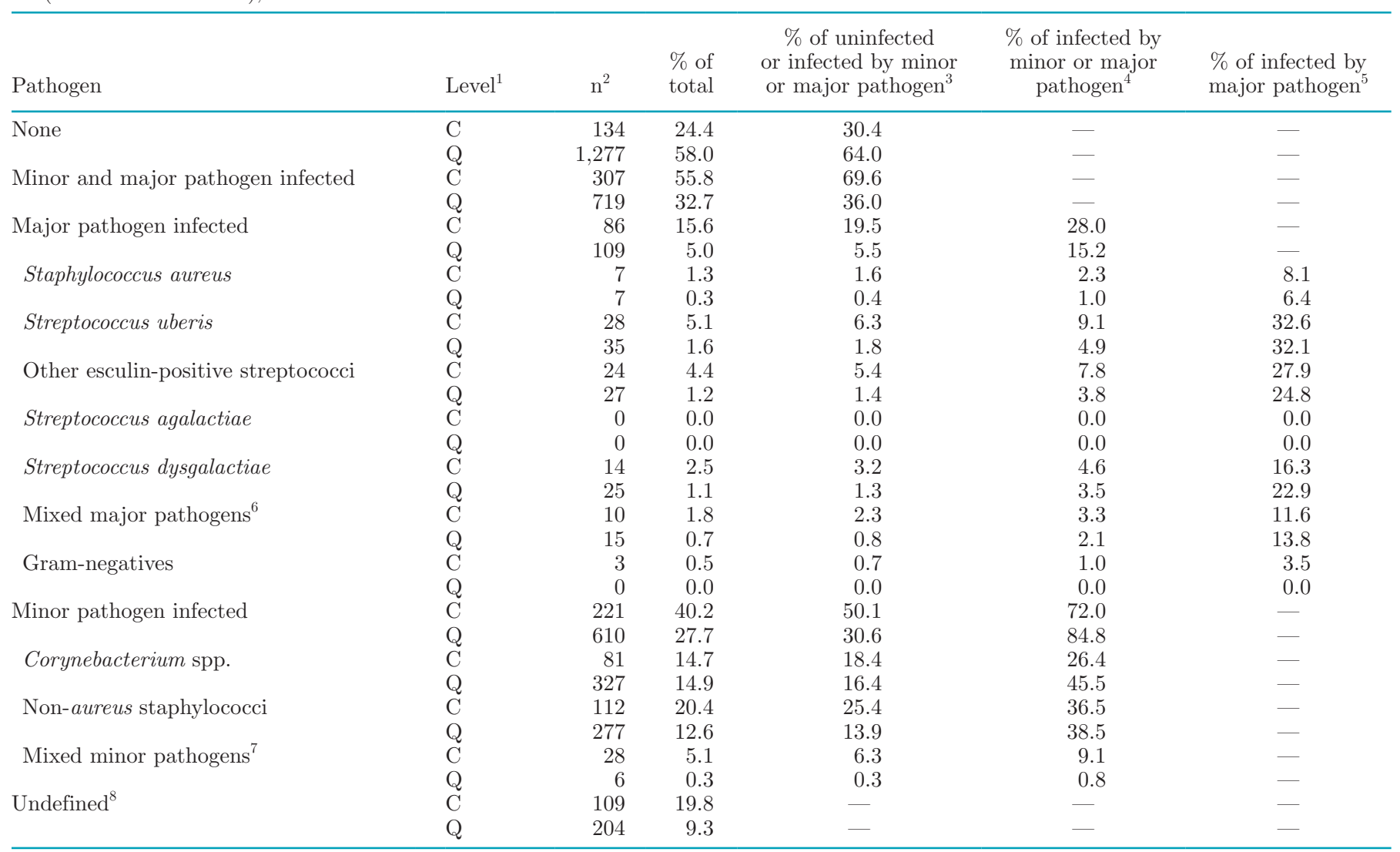

${ }^{1} \mathrm{C}=$ cow IMI status, based on quarter-level bacteriological culture; $\mathrm{Q}=$ quarter, based on quarter-level bacteriological culture.

${ }^{2}$ Number of cows $(\mathrm{C})$ or quarters $(\mathrm{Q})$.

${ }^{3}$ Cows $(\mathrm{n}=441)$ and quarters $(\mathrm{n}=1,996)$ defined as uninfected or infected with one or more minor or major pathogens.

${ }^{4}$ Cows $(\mathrm{n}=307)$ and quarters $(\mathrm{n}=719)$ defined as infected with one or more minor or major pathogens.

${ }^{5}$ Cows $(\mathrm{n}=86)$ and quarters $(\mathrm{n}=109)$ defined infected with one or more major pathogens.

${ }^{6}$ Mixed major pathogens per cow: esculine-positive streptococci/esculine-negative streptococci ( $\mathrm{n}=1$ ); esculine-positive streptococci/gramnegatives $(\mathrm{n}=2)$.

${ }^{7}$ Mixed minor pathogens per cow: non-aureus staphylococci and Corynebacterium spp.

${ }^{8}$ Of the 109 cows, $81(74.3 \%)$ had at least 1 contaminated quarter, 2 cows $(1.8 \%)$ were infected with fungi, whereas none of the quarters were infected with yeast. Then, 26 cows $(23.9 \%)$ were infected with Bacillus spp. withholding the cow from being considered culture negative. None of the quarters were infected with yeast, and 19 quarters were blind.

1) before drying off were collected at on average 256, 293, and 330 DIM, respectively.

\section{Diagnostic Properties}

The test characteristics and predictive values ( $\mathrm{Se}, \mathrm{Sp}$, NPV, and PPV, respectively) of single and multiple SCC were calculated to differentiate between majorpathogen-infected cows (such cows are considered in need of treatment with long-acting antimicrobials at drying off) and cows that were either uninfected or minor pathogen infected (such cows should not be treated with antimicrobials at drying off) at drying off. Culture results at drying off were used as the gold standard for the IMI status of the cow, and different
SCC thresholds, ranging between 50,000 and 500,000 cells/mL, above which the test was defined as positive, were tested in $2 \times 2$ tables as described by Dohoo et al. (2003) and as applied by for instance Jashari et al. (2016). For evaluation of the diagnostic properties of geoSCC DHI-123, the test was considered positive when the geometric mean of SCC DHI-1, SCC DHI-2, and SCC DHI-3 exceeded the threshold. For evaluation of the diagnostic properties of sumSCC DHI-123, the test was considered positive when the sum of the number of times one of the SCC measurements (SCC DHI-1, SCC DHI-2, and SCC DHI-3) exceeded the threshold, was $\geq 1$. The Youden's index (\%) was calculated using the following formula: Se $+\mathrm{Sp}-100$ (Youden, 1950), for different SCC thresholds, ranging between 50,000 and 
500,000 cells $/ \mathrm{mL}$ as was done by for instance Jashari et al. (2016).

Calculations were repeated for the different herdand-cow strata (LP and HP herds, LY and HY cows, and heifers and multiparous cows) using a somewhat smaller number of different SCC thresholds.

The significance of differences in test characteristics and predictive values was assessed based on the overlap between 95\% CI (Jashari et al., 2016).

\section{RESULTS}

\section{Descriptive Results}

Bacteriological Culturing. Out of the 550 cows, $134(24.4 \%), 221(40.2 \%)$, and $86(15.6 \%)$ cows were defined as uninfected, minor pathogen infected, and major pathogen infected, respectively, resulting in a subset of 441 cows (Table 1). One hundred nine out of the 550 enrolled cows (19.8\%) had an undefined IMI status and were thus redundant for further analyses. This was mostly due to contamination of 1 or 2 quarter milk samples out of 4 (in 51.4 and $13.8 \%$ of the 109 cows, respectively), albeit in $23.9 \%$ of the cows only Bacillus spp. was isolated in one or more quarters excluding these cows from the data set.

Out of the 2,200 quarters, 1,277 (58.0\%), 610 (27.7\%), and $109(5.0 \%)$ quarters were defined as uninfected, minor pathogen infected, and major pathogen infected, respectively (Table 1). Besides, 185 undefined quarters $(8.4 \%)$ and 19 blind quarters $(0.9 \%)$ were observed.

Somatic Cell Counting. Considering the 441 cows in data set SCC DHI-1, the geometric mean SCC DHI-1 was 110,000 cells/mL (interquartile range 49,000-231,000 cells $/ \mathrm{mL}$ ). For the 433 cows in data set SCC DHI-123, the average of the geometric mean of the last 3 test-day SCC before drying off (geoSCC DHI123) was 94,000 cells $/ \mathrm{mL}$ (interquartile range between 44,000 and 187,000 cells $/ \mathrm{mL}$ ). The average sum of the number of times one of the last 3 SCC measurements (sumSCC DHI-123) exceeded a 200,000 and 500,000 cells $/ \mathrm{mL}$ threshold, was 0.75 (range $0-3$ ) and 0.23 (range 0-3), respectively. Overall, SCC values [SCC DHI- $1\left(\mathrm{n}_{\text {cows }}=441\right)$, and geoSCC DHI- 123 and sumSCC DHI-123 $\left.\left(\mathrm{n}_{\text {cows }}=433\right)\right]$ were lowest in uninfected cows, somewhat higher in minor-pathogen-infected cows, and highest in the major-pathogen-infected cows (Table 2). More specific, values were higher in low-yielding cows and in multiparous cows, irrespective of their infection statuses, whereas a specific trend was not present when looking at the values as a function of the herd subclinical mastitis prevalence (Table 2).

\section{Overall Diagnostic Properties}

Numerically, the Se decreased and the Sp increased for all tested thresholds of the different SCC criteria (SCC DHI-1, geoSCC DHI-123, and sumSCC DHI-123) when a higher threshold level (i.e., 50, 100, 150, 200, 250 , and $500 \times 1,000$ cells $/ \mathrm{mL}$ ) was used to detect cows infected with (a) major pathogen(s). This was statistically confirmed when looking at the $95 \%$ confidence intervals $(\mathbf{9 5 \%} \mathbf{C I})$, except when comparing the 200,000 with the 250,000 cells $/ \mathrm{mL}$ thresholds. As well, overlap of the $95 \%$ CI was observed for geoSCC DHI-123 between the 150,000 and 200,000 cells/mL threshold and sumSCC DHI-123 between the 100,000 and 150,000 cells/mL thresholds. The highest and lowest Se (i.e., 89.4 and $12.9 \%$, respectively) was observed for sumSCC DHI-123 threshold of 50,000 cells/mL and geoSCC DHI-123 threshold of 500,000 cells/mL, respectively. The highest and lowest Sp (i.e., 95.4 and $20.1 \%$, respectively) was observed for the geoSCC DHI-123 threshold of 500,000 cells $/ \mathrm{mL}$ and sumSCC DHI- 123 threshold of 50,000 cells $/ \mathrm{mL}$, respectively. Looking at the $95 \%$ CI between the SCC criteria (i.e., SCC DHI-1, geoSCC, and sumSCC), differences in Se and Sp were overall limited (Table 3), meaning for most thresholds overlap of the $95 \%$ CI was present. Albeit, a higher Se was observed for sumSCC DHI-132 at thresholds $150,000,200,000$, and 250,000 cells $/ \mathrm{mL}$, whereas a lower Sp was observed at thresholds 50,000 and 500,000 cells/mL compared with SCC DHI-1 and geoSCC DHI123 using the same cut-offs.

The PPV increased numerically and the NPV decreased numerically for SCC DHI-1, geoSCC DHI-123, and sumSCC DHI-123, when an increasing threshold level of SCC (i.e., 50, 100, 150, 200, 250, and $500 \times$ 1,000 cells $/ \mathrm{mL}$ ) was used, with the exceptions of sumSCC DHI-123 threshold of 50,000 and 100,000 cells/mL and geoSCC DHI-123 threshold of 200,000 and 250,000 cells/mL, as an equal NPV was observed. A statistical difference was only present for SCC DHI-1 between the 50,000 and 100,000 cells/mL thresholds and between the 250,000 and 500,000 cells/mL thresholds. The highest and lowest PPV (45.0 and $21.5 \%$, respectively) was observed for the SCC DHI-1 threshold of 500,000 cells/ $\mathrm{mL}$ and sumSCC DHI-123 threshold 50,000 cells/mL, whereas the highest and lowest NPV (89.5 and 81.8\%, respectively) were observed for the SCC DHI-1 threshold of 50,000 cells/mL and geoSCC DHI-123 threshold of 50,000 cells/mL. Looking at the $95 \%$ CI, differences in PPV and NPV seem comparable between the SCC criteria (Table 3 ).

The highest Y (i.e., 26.5\%) was observed using geoSCC DHI-123 for cows infected with (a) major 
LIPKENS ET AL.

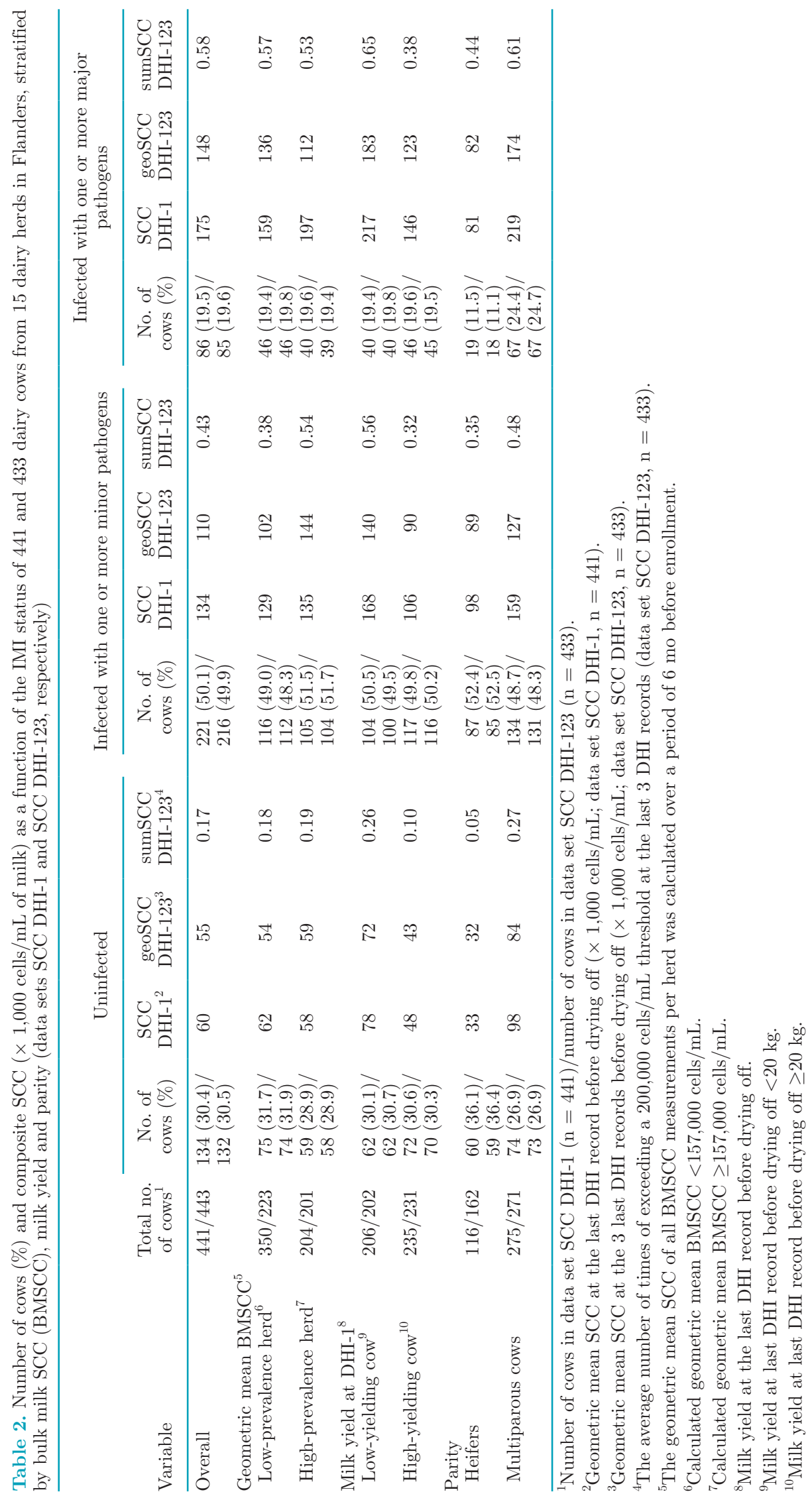


Table 3. Sensitivity (Se), specificity (Sp), positive predictive value (PPV), and negative predictive value (NPV) with 95\% CI of composite milk SCC to differentiate between cows infected with one or more major pathogens at drying off and cows that were either uninfected or minor pathogen infected (with bacteriological culturing serving as the gold standard; data sets SCC DHI-1 and SCC DHI-123)

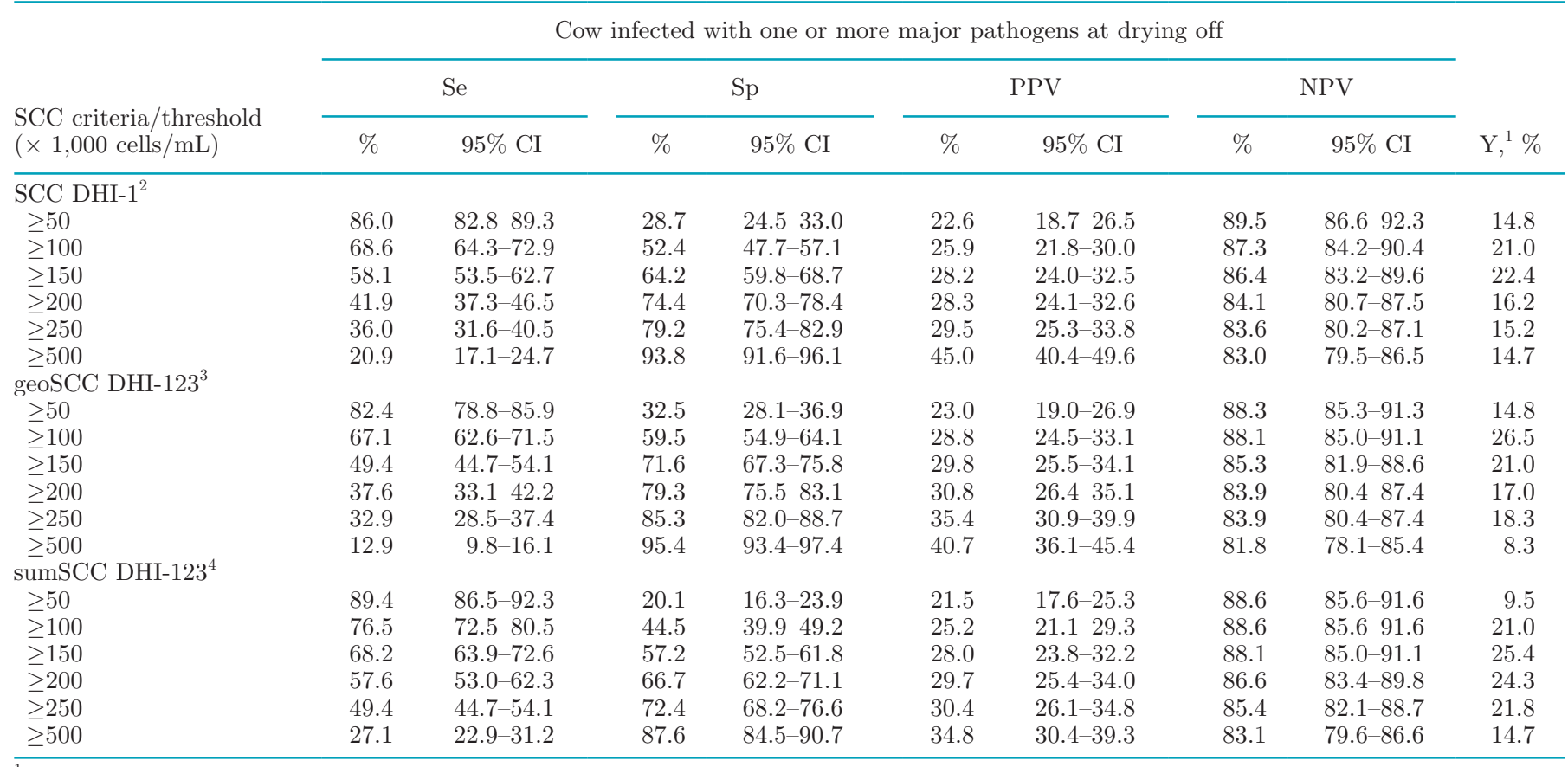

${ }^{1}$ Youden's index $=\mathrm{Se}+\mathrm{Sp}-100$.

${ }^{2} \mathrm{SCC}$ at the last DHI record before drying off.

${ }^{3}$ Geometric mean of SCC at the last 3 DHI records before drying off. The test was considered positive when the geometric mean of the SCC DHI-1, SCC DHI-2, and SCC DHI-3 exceeded the threshold.

${ }^{4}$ The test was considered positive when the sum of the number of times one of the SCC measurements (SCC DHI-1, SCC DHI-2, and SCC DHI3) exceeded the threshold was $\geq 1$.

pathogen(s) at a threshold of 100,000 cells/mL (Table $3)$.

\section{Diagnostic Properties Over the Different Herd- and Cow-Level Strata}

Sensitivity, Sp, PPV, and NPV were somewhat different when comparing overall estimates with the strata-specific estimates (Tables 4, 5, and 6).

For all 3 SCC strata (i.e., SCC DHI-1, geoSCC DHI123, and sumSCC DHI-123), no statistically different test characteristics and predictive values were observed between LP and HP herds when comparing the different thresholds. Still, numerically, a higher Sp was observed in LP herds compared with HP herds, which was also true for the PPV for both the geoSCC DHI123 and sumSCC DHI-123 criteria.

When comparing LY cows with HY cows, the Se was significantly higher whereas the Sp was lower, with an exception for SCC DHI-1 at 50,000 cells $/ \mathrm{mL}$ for all 3 SCC criteria (SCC DHI-1, geoSCC DHI-123, and sumSCC DHI-123). Thus, no overlap was observed in $95 \%$ CI except for Se at the SCC DHI-1 at 50,000 cells/ $\mathrm{mL}$ but also at sumSCC DHI-123 at 50,000 cells/mL.
The PPV was lower in LY than in HY cows, and only for geoSCC DHI-123, a small increase of NPV was observed in LY when compared with HY cows, which was not statistically confirmed because of overlap between 95\% CI.

When comparing multiparous cows and heifers, the Se was significantly higher whereas the Sp was lower. A numerical difference exists between the multiparous cows and heifers (higher PPV and lower NPV), although a statistical difference for the PPV of all tested thresholds was only seen for sumSCC DHI-123.

\section{DISCUSSION}

Somatic cell count data obtained via the regular DHI program from a large number of cows housed on 15 commercial dairy farms with good mastitis management were evaluated to predict IMI with major pathogens in dairy cattle before drying off. It was revealed that test-day SCC records obtained via milk recording are reliable to detect uninfected/minor-pathogen-infected dairy cows at drying off as determined by bacteriological culture, serving as the gold standard, and can be used to differentiate (likely) major pathogen infected 
and uninfected or minor-pathogen-infected cows at drying off in commercial dairy herds when implementing SDCT.

Non-aureus staphylococci together with Corynebacterium spp. are minor pathogens and lack the ability to cause severe clinical mastitis cases (Huxley et al., 2004; Taponen et al., 2009). They cause only a modest increase in the SCC, and the effect of non-aureus staphylococci on milk yield, being positive or negative, is disputed (e.g., Schukken et al., 2009; Piepers et al., 2010, 2013; Heikkilä et al., 2018). As well, they colonize the teat canal and thus do not always represent an IMI when cultured from milk (Hiitiö et al., 2016), whereas some studies suggest they might be of protective nature against major pathogen infections (Schukken et al., 2009; Blagitz et al., 2013). Further, non-aureus staphylococcal infections are often of transient nature and spontaneous elimination rates without any treatment up to $70 \%$ have been reported (McDougall, 1998; Wilson et al., 1999). This also explains why in some countries, it is common practice to leave subclinical and mild clinical mastitis caused by non-aureus staphylococci untreated (Pyörälä and Taponen, 2009; Taponen et al., 2009). Therefore, in Norway, dry cow treatment

Table 4. Number of cows, sensitivity (Se), specificity (Sp), positive predictive value (PPV), and negative predictive value (NPV) with 95\% CI of last test-day composite milk SCC (SCC DHI-1) to differentiate between cows infected with one or more major pathogens at drying off and cows that were either uninfected or minor pathogen infected (with bacteriological culturing serving as the gold standard), when the threshold was set at SCC DHI-1 $>50,000, \geq 100,000, \geq 200,000$ cells $/ \mathrm{mL}$, stratified by bulk milk SCC (BMSCC), milk yield, and parity groups (data set SCC DHI-1)

\begin{tabular}{|c|c|c|c|c|c|c|c|c|c|c|}
\hline \multirow[b]{3}{*}{ Stratum } & \multirow{3}{*}{$\begin{array}{c}\mathrm{n}, \\
\text { cows }\end{array}$} & \multirow{3}{*}{$\begin{array}{c}\text { SCC DHI- }^{1} \\
\text { thresholds } \\
(\times 1,000 \text { cells } / \mathrm{mL})\end{array}$} & \multicolumn{8}{|c|}{ Cow infected with one or more major pathogens at drying off } \\
\hline & & & \multicolumn{2}{|r|}{$\mathrm{Se}$} & \multicolumn{2}{|r|}{$\mathrm{Sp}$} & \multicolumn{2}{|r|}{ PPV } & \multicolumn{2}{|c|}{ NPV } \\
\hline & & & $\%$ & $95 \% \mathrm{CI}$ & $\%$ & $95 \% \mathrm{CI}$ & $\%$ & $95 \% \mathrm{CI}$ & $\%$ & $95 \% \mathrm{CI}$ \\
\hline \multirow[t]{4}{*}{ All cows ${ }^{2}$} & 441 & & & & & & & & & \\
\hline & & $\geq 50$ & 86.0 & $82.8-89.3$ & 28.7 & $24.5-33.0$ & 22.6 & $18.7-26.5$ & 89.5 & $86.6-92.3$ \\
\hline & & $\geq \overline{100}$ & 68.6 & $64.3-72.9$ & 52.4 & $47.7-57.1$ & 25.9 & $21.8-30.0$ & 87.3 & $84.2-90.4$ \\
\hline & & $\geq 200$ & 41.9 & $37.3-46.5$ & 74.4 & $70.3-78.4$ & 28.3 & $24.1-32.6$ & 84.1 & $80.7-87.5$ \\
\hline \multicolumn{11}{|l|}{ Geometric mean BMSCC ${ }^{3}$} \\
\hline \multirow[t]{4}{*}{ Low-prevalence herd ${ }^{4}$} & 237 & & & & & & & & & \\
\hline & & $\geq 50$ & 82.6 & $77.8-87.4$ & 30.9 & $25.0-36.8$ & 22.4 & $17.0-27.7$ & 88.1 & $83.9-92.2$ \\
\hline & & $\geq \overline{100}$ & 69.6 & $63.7-75.4$ & 57.6 & $51.3-63.9$ & 28.3 & $22.6-34.1$ & 88.7 & $84.7-92.7$ \\
\hline & & $\geq 200$ & 39.1 & $32.9-45.3$ & 75.4 & $69.9-80.9$ & 27.7 & $22.0-33.4$ & 83.7 & $79.0-88.4$ \\
\hline \multirow{4}{*}{ High-prevalence herd ${ }^{5}$} & 204 & & & & & & & & & \\
\hline & & $\geq 50$ & 90.0 & $85.9-94.1$ & 26.2 & $20.2-32.3$ & 22.9 & $17.2-28.7$ & 91.5 & $87.7-95.3$ \\
\hline & & $\geq \overline{1} 00$ & 67.5 & $61.1-73.9$ & 46.3 & $39.5-53.2$ & 23.5 & $17.7-29.3$ & 85.4 & $80.5-90.2$ \\
\hline & & $\geq 200$ & 45.0 & $38.2-51.8$ & 73.2 & $67.1-79.3$ & 29.0 & $22.8-35.3$ & 84.5 & $79.5-89.5$ \\
\hline \multicolumn{11}{|l|}{ Milk yield at DHI- $1^{6}$} \\
\hline \multirow[t]{4}{*}{ Low $^{7}$} & 206 & & & & & & & & & \\
\hline & & $\geq 50$ & 85.0 & $80.1-89.9$ & 18.7 & $13.4-24.0$ & 20.1 & $14.6-25.6$ & 83.8 & $78.8-88.8$ \\
\hline & & $\geq \overline{100}$ & 80.0 & $74.5-85.5$ & 42.2 & $35.4-48.9$ & 25.0 & $19.1-30.9$ & 89.7 & $85.6-93.9$ \\
\hline & & $\geq 200$ & 55.0 & $48.2-61.8$ & 63.9 & $57.3-70.4$ & 26.8 & $20.8-32.9$ & 85.5 & $80.7-90.3$ \\
\hline \multirow[t]{4}{*}{$\operatorname{High}^{8}$} & 235 & & & & & & & & & \\
\hline & & $\geq 50$ & 87.0 & $82.7-91.3$ & 37.6 & $31.4-43.8$ & 25.3 & $19.8-30.9$ & 92.2 & $88.8-95.6$ \\
\hline & & $\geq \overline{100}$ & 58.7 & $52.4-65.0$ & 61.4 & $55.2-67.6$ & 27.0 & $21.3-32.7$ & 85.9 & $81.5-90.4$ \\
\hline & & $\geq 200$ & 30.4 & $24.6-36.3$ & 83.6 & 78.9-88.3 & 31.1 & $25.2-37.0$ & 83.2 & $78.4-87.9$ \\
\hline \multicolumn{11}{|l|}{ Parity } \\
\hline \multirow[t]{4}{*}{ Heifers } & 166 & & & & & & & & & \\
\hline & & $\geq 50$ & 57.9 & $50.4-65.4$ & 49.0 & 41.4-56.6 & 12.8 & $7.7-17.9$ & 90.0 & $85.4-94.6$ \\
\hline & & $\geq \overline{1} 00$ & 52.6 & $45.0-60.2$ & 69.4 & $62.4-76.4$ & 18.2 & $12.3-24.0$ & 91.9 & $87.7-96.0$ \\
\hline & & $\overline{\geq} 200$ & 15.8 & $10.2-21.3$ & 84.4 & $78.8-89.9$ & 11.5 & $6.7-16.4$ & 88.6 & $83.7-93.4$ \\
\hline \multirow[t]{4}{*}{ Multiparous } & 275 & & & & & & & & & \\
\hline & & $\geq 50$ & 94.0 & $91.2-96.8$ & 14.4 & $10.3-18.6$ & 26.1 & 20.9-31.3 & 88.2 & $84.4-92.0$ \\
\hline & & $\geq \overline{100}$ & 73.1 & $67.9-78.4$ & 40.4 & $34.6-46.2$ & 28.3 & $23.0-33.6$ & 82.4 & $77.8-86.9$ \\
\hline & & $\geq 200$ & 49.3 & $43.3-55.2$ & 67.3 & $61.8-72.9$ & 32.7 & $27.1-38.2$ & 80.5 & $75.8-85.1$ \\
\hline
\end{tabular}

${ }^{1} \mathrm{SCC}$ at the last DHI record before drying off.

${ }^{2}$ All cows defined as uninfected, minor pathogen infected, and major pathogen infected.

${ }^{3}$ The geometric mean SCC of all BMSCC measurements per herd was calculated over a period of 6 mo before enrollment.

${ }^{4}$ Calculated geometric mean BMSCC $<157,000$ cells $/ \mathrm{mL}$.

${ }^{5}$ Calculated geometric mean BMSCC $\geq 157,000$ cells $/ \mathrm{mL}$.

${ }^{6}$ Milk yield at the last DHI record before drying off.

${ }^{7}$ Milk yield at last DHI record before drying off $<20 \mathrm{~kg}$.

${ }^{8}$ Milk yield at last DHI record before drying off $\geq 20 \mathrm{~kg}$. 
Table 5. Number of cows, sensitivity (Se), specificity (Sp), positive predictive value (PPV), and negative predictive value (NPV) with 95\% CI of 3 last composite milk SCC (geoSCC DHI-123) to differentiate between cows infected with one or more major pathogens at drying off and cows that were either uninfected or minor pathogen infected (with bacteriological culturing serving as the gold standard), when the threshold was set at geoSCC DHI- $123 \geq 50,000, \geq 100,000, \geq 200,000$ cells/mL, stratified by bulk milk SCC (BMSCC), milk yield, and parity groups (data set SCC DHI-123)

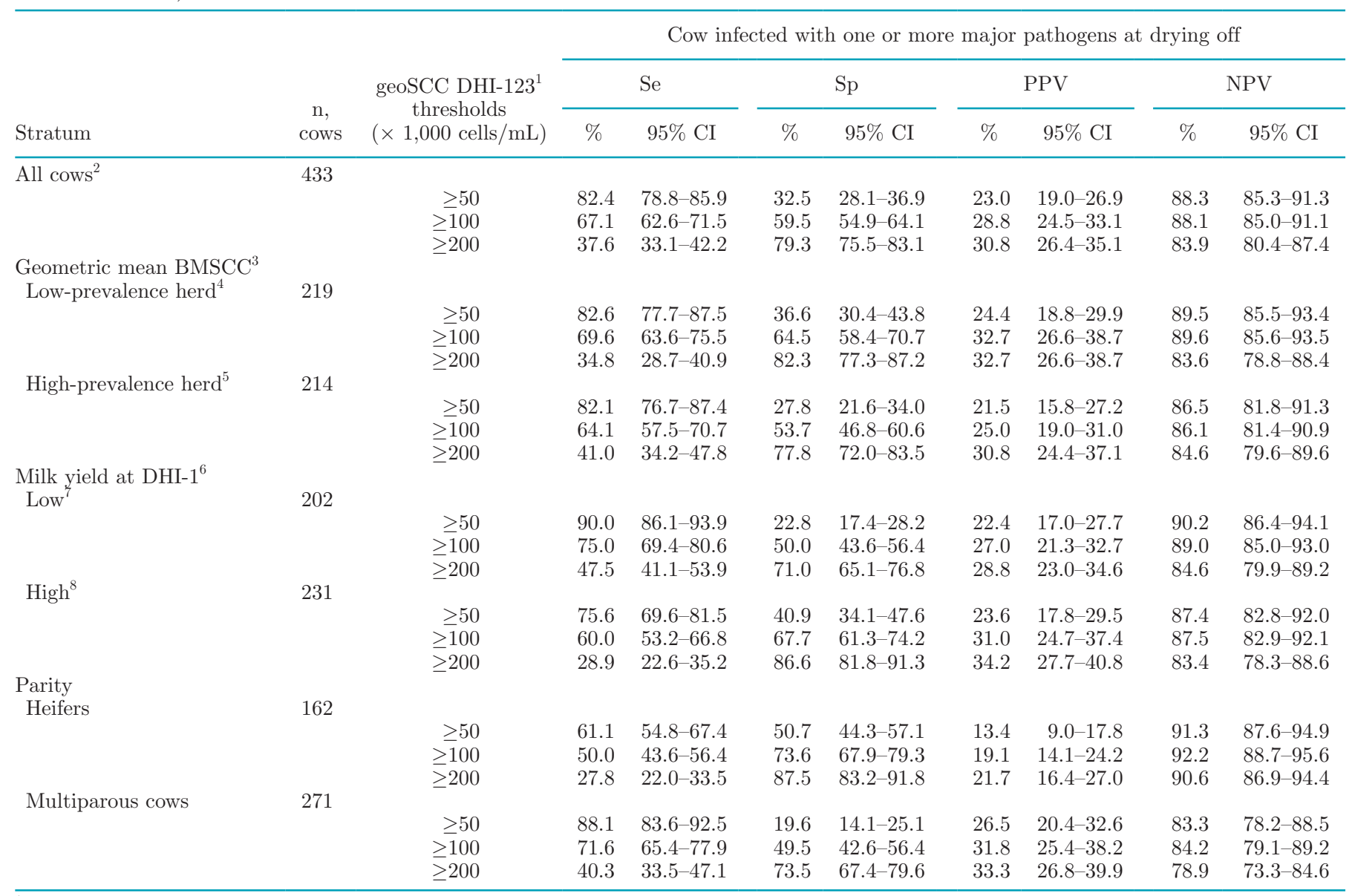

${ }^{1}$ Geometric mean of SCC at the last 3 DHI records before drying off. The test was considered positive when the geometric mean of the SCC DHI-1, SCC DHI-2, and SCC DHI-3 exceeded the threshold.

${ }^{2}$ All cows defined as uninfected, minor pathogen infected, and major pathogen infected.

${ }^{3}$ The geometric mean SCC of all BMSCC measurements per herd was calculated over a period of 6 mo before enrollment.

${ }^{4}$ Calculated geometric mean BMSCC $<157,000$ cells $/ \mathrm{mL}$.

${ }^{5}$ Calculated geometric mean BMSCC $\geq 157,000$ cells $/ \mathrm{mL}$.

${ }^{6}$ Milk yield at the last DHI record before drying off.

${ }^{7}$ Milk yield at last DHI record before drying off $<20 \mathrm{~kg}$.

${ }^{8}$ Milk yield at last DHI record before drying off $\geq 20 \mathrm{~kg}$.

is only recommended if cows are infected with $S$. aureus, S. dysgalactiae, or other major pathogens, leaving minor-pathogen-infected cows untreated at drying off (Osterås and Sølverød, 2009). In conclusion, we strongly believe that good stewardship of antimicrobials only includes treating major-pathogen-infected cows with antimicrobials at drying off. Therefore, this study aimed at differentiating major-pathogen-infected cows from uninfected or minor-pathogen-infected cows.

When deciding what SCC information to use, only the last test-day SCC versus multiple test-day SCC, it depends whether one aims at a high Se (low num- ber of false negatives) or high Sp (low number of false positives), or a combination (highest $\mathrm{Y}$ ). If the latter is the choice, using geoSCC DHI-123 at a threshold of 100,000 cells $/ \mathrm{mL}$ is the best option based on our data, yet if one wants to aim for, for example, the highest Se, then sumSCC DHI-123 at a threshold of 50,000 cells/ $\mathrm{mL}$ has to be selected. Still, as SCC information is used to predict the IMI status of cows, in this particular study at drying off, it makes sense to focus on the predictive values. When looking for test-day information yielding the highest PPV (i.e., SCC DHI-1 at a threshold of 500,000 cells $/ \mathrm{mL}$ in our data), one reduces 
Table 6. Number of cows, sensitivity (Se), specificity (Sp), positive predictive value (PPV), and negative predictive value (NPV) with 95\% CI of 3 last composite milk SCC (sumSCC DHI-123) to differentiate between cows infected with one or more major pathogens at drying off and cows that were either uninfected or minor pathogen infected (with bacteriological culturing serving as the gold standard), when the threshold was set at sumSCC DHI- $123 \geq 50,000, \geq 100,000, \geq 200,000$ cells $/ \mathrm{mL}$, stratified by bulk milk SCC (BMSCC), milk yield, and parity groups (data set SCC DHI-123)

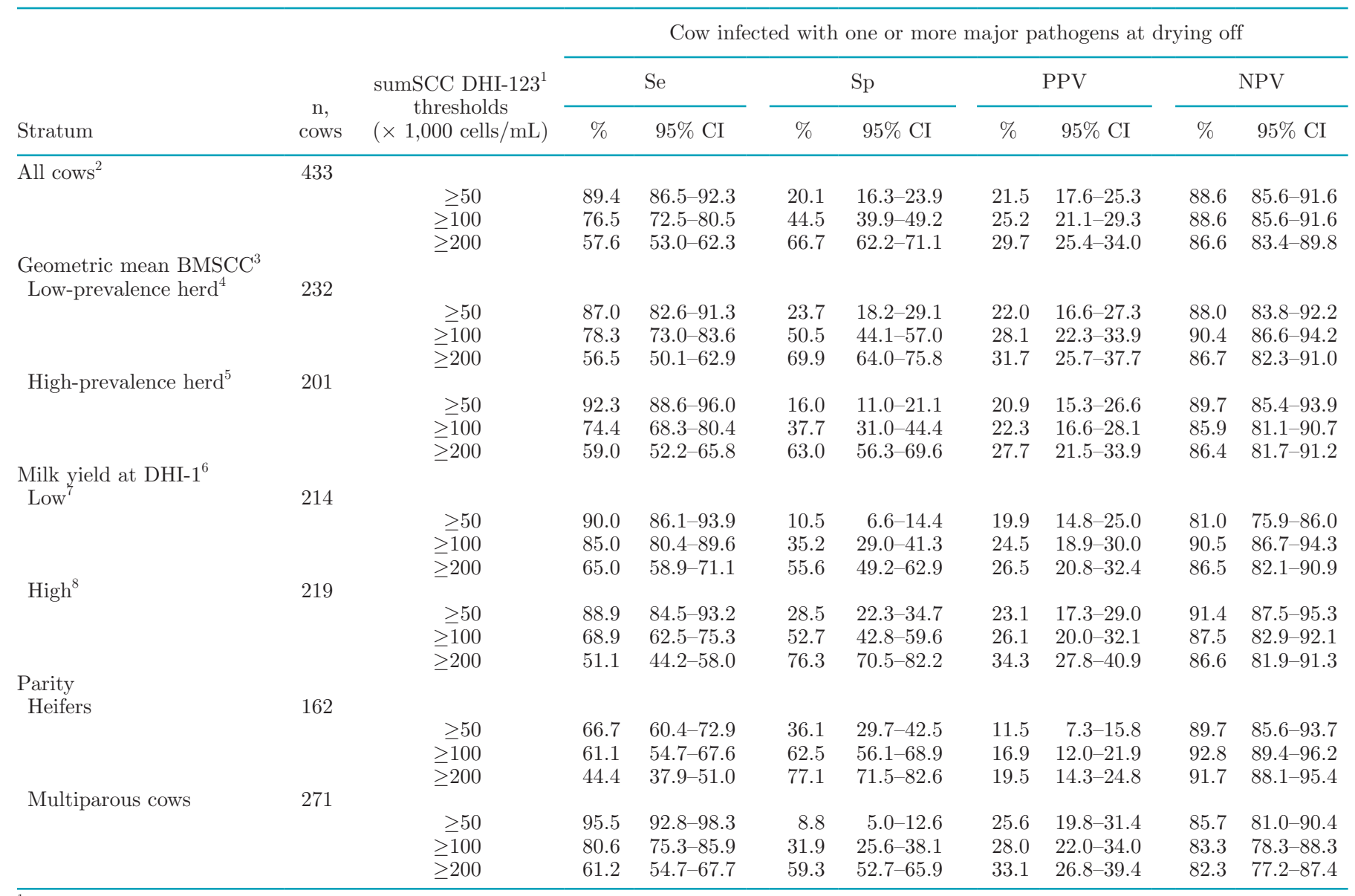

${ }^{1}$ The test was considered positive when the sum of the number of times one of the SCC measurements (SCC DHI-1, SCC DHI-2, and SCC DHI3) exceeded the threshold was $\geq 1$.

${ }^{2}$ All cows defined as uninfected, minor pathogen infected, and major pathogen infected.

${ }^{3}$ The geometric mean SCC of all BMSCC measurements per herd was calculated over a period of 6 mo before enrollment.

${ }^{4}$ Calculated geometric mean BMSCC $<157,000$ cells $/ \mathrm{mL}$.

${ }^{5}$ Calculated geometric mean BMSCC $\geq 157,000$ cells $/ \mathrm{mL}$.

${ }^{6}$ Milk yield at the last DHI record before drying off.

${ }^{7}$ Milk yield at last DHI record before drying off $<20 \mathrm{~kg}$.

${ }^{8}$ Milk yield at last DHI record before drying off $\geq 20 \mathrm{~kg}$.

the likelihood of treating uninfected/minor-pathogeninfected cows with antimicrobials unnecessarily, which is what society would ask as part of the demand to reduce antimicrobial use. If, however, the risk of not treating an infected cow with antimicrobials has to be minimal (avoiding welfare issues for the cows and economic losses for the farmer), one wants to use the SCC information that comes with the highest NPV (i.e., SCC DHI-1 at a threshold of 50,000 cells $/ \mathrm{mL}$ ).

Caution is needed when comparing estimates of test characteristics between studies due to different definitions of IMI and prevalence of mastitis pathogens in the herds. For instance, lower Se and Sp than reported by Torres et al. (2009) were expected because minorpathogen-infected cows were included in the group of cows that would not be considered in need of antimicrobials. Likewise, Pantoja et al. (2009) found inferior test characteristics when using SCC in herds with low levels of contagious pathogens, where minor pathogen infections dominated, probably due to a less intense SCC response regarding these pathogens (Cameron et al., 2011). Also, late-lactation milk composition differs from the milk composition throughout the lactation, characterized by a physiological increase in the SCC 
(thus more false positives) as a consequence of the decreasing milk yield (Green et al., 2006). Combining multiple test-day SCC before drying off seemingly overcomes this bias, as a higher Sp was achieved for geoSCC DHI-123 compared with SCC DHI-1.

Ideally, SDCT is applied based on bacteriological culturing at drying off, to ensure justified and correct use of antimicrobials. The Petrifilm on-farm culture system reduced the use of dry cow therapy without negatively affecting milk production and milk quality, albeit all cows with a positive culture result, thus including minor pathogens, received antimicrobial treatment (Cameron et al., 2015). Several studies aimed at finding more practical and financially feasible alternatives, and reported promising results for SCC, estimating the inflammation status rather than the infection status. Rajala-Schultz et al. (2011) demonstrated that selectively drying off low SCC cows without antimicrobials has no negative effect on MY in next lactation, yet the effect varied between herds. Vasquez et al. (2018) reported no difference in SCC, clinical mastitis, and culling events after calving between the treatment groups (treated with antimicrobials and teat sealer versus only treated with teat sealers) as well, confirming that SCC data are reliable in differentiating infected from uninfected cows. Our study supports these approaches, and we recommend adapting SCC thresholds as a function of the herd-level prevalence of subclinical mastitis, for example, using BMSCC as an indicator, and as a function of the milk yield (preferably measured at drying off) and parity of each specific cow.

We came to this conclusion as overall estimates of the test characteristics and predictive values differ to some extent from the strata-specific estimates, even with overlapping $95 \%$ CI (driven by sample size). Aiming at maximizing the chance of only withholding antimicrobials from truly uninfected cows, to maximally protect the udder health, implies that SCC criteria and thresholds with the highest NPV are the best choice. As an example, one could consider to work with the last test-day SCC only (SCC DHI-1) as it comes with the highest NPV, yet with a threshold of 100,000 cells/ $\mathrm{mL}$ for a heifer and a threshold of 50,000 cells/mL for a multiparous cow when deciding whether it is (likely) major pathogen infected (and needs long-acting dry cows tubes) or not (and needs no antimicrobial treatment and only needs to be protected from new IMI). It could eventually become even more sophisticated when test-characteristics and predictive values for different SCC combinations and different SCC thresholds are available for (e.g., heifers managed in HP or LP herds), as this comes with additional changes in thresholds that can be used for specific SCC combinations. Based on our data (see Appendix Table A1) and aiming at the highest NPV, this would result in using sumSCC DHI-123 with a threshold of 50,000 cells/mL for heifers and multiparous cows in HP herds, and a threshold of 150,000 and 100,000 cells $/ \mathrm{mL}$ for heifers and multiparous cows in LP herds, respectively. Simulating a 1,000 cow LP and HP herd using the proposed thresholds above, thus aiming at the highest NPV, on the exact same data from our study (see Appendix Table A1), 474 cows $(47.4 \%)$ would be considered uninfected $/ \mathrm{mi}$ nor pathogen infected by use of the test in a LP herd, of which 17 heifers (3.6\%) and 26 multiparous cows (5.5\%) falsely would not receive antimicrobials at drying off as they were infected with a major pathogen in at least one quarter (high NPV). Then, out of the 526 cows $(52.6 \%)$ that would be considered infected by use of the test and therefore receive treatment at drying off, 65 heifers $(12.3 \%)$ and 306 multiparous cows $(58.2 \%)$ were actually uninfected/minor pathogen infected at drying off (low PPV). In a HP herd, 144 cows (14.4\%) would be considered uninfected/minor pathogen infected by use of the test, of which only 10 heifers $(6.9 \%)$ and 5 multiparous cows $(3.4 \%)$ would falsely not receive antimicrobials at drying off (very high NPV). Then, out of the 856 cows $(85.6 \%)$ that would be considered infected by use of the test and therefore receive treatment at drying off, 239 heifers (27.9\%) and 438 multiparous cows $(51.2 \%)$ were uninfected/minor pathogen infected at drying off (low PPV). Implementing this type of approach is feasible when an algorithm based on DHI information (e.g., milk yield, parity) and an estimate of the herd-level prevalence (BMSCC information is readily available) is created and used every time a specific cow has to be dried off. This would support farmers and farm managers in taking scientifically sound and data-driven decisions when it comes to antimicrobial stewardship and good (dry cow) mastitis management.

We acknowledge that an alternative to BMSCC to estimate the likely prevalence of subclinical mastitis in a herd is the use of the average herd SCC derived from DHI recording. Still, other studies have used BMSCC to categorize herds in a manner relevant for udder health. For instance, Barkema et al. (1999) stratified herds based on the average BMSCC, using thresholds in the range of the current study: $\leq 150,000$ cells $/ \mathrm{mL}$ (low), 151,000 to 250,000 cells $/ \mathrm{mL}$, and 251,000 to 400,000 cells/mL (high). Clinical mastitis caused by gram-negative pathogens occurred more often in herds with a low BMSCC, whereas clinical mastitis caused by Staphylococcus aureus, Streptococcus dysgalactiae, and Streptococcus agalactiae occurred more often in herds with a high BMSCC. Besides, BMSCC information is easily accessible, does not take into account herd size, and is also used to determine the milk quality, which is legally limited to 400,000 cells/mL in Europe, and 
it therefore remains a valuable tool for udder health management.

The next step will be to use the current data to implement SDCT on commercial dairy herds comparing the performances of cows that were selectively dried off with those receiving blanket dry cow therapy. Monitoring the cows' performances and welfare after drying off will allow to quantify the consequences (udder health, longevity, antimicrobial use, milk production) of herds shifting from blanket dry cow therapy to SDCT.

\section{CONCLUSIONS}

Composite SCC data were studied to differentiate between infected [i.e., infected with (a) major pathogen(s)] and uninfected cows [i.e., uninfected or infected with (a) minor pathogen(s)] at drying off. At the threshold of 50,000 cells $/ \mathrm{mL}$, the Se and Sp of (a combination of) test-day SCC information before drying off range between 82.4 and 89.4 and between 20.1 and 32.5\%, respectively, whereas at a threshold of 500,000 cells/ $\mathrm{mL}$ the respective values are $12.9,27.1$ and 87.6 and $95.4 \%$. As the prevalence of subclinical mastitis in the herd, the cow's milk yield, and parity before drying off influence the estimates, these factors could be taken into account when choosing (a) SCC threshold(s), for example, when implementing a selective dry cow approach on the farm. In conclusion, composite SCC available through milk recording can provide reliable and easily accessible estimates for identifying cows that are uninfected or minor-pathogen-infected cows at drying off and do not need antimicrobial treatment.

\section{ACKNOWLEDGMENTS}

This research was supported by grant no. 141088 of the Research Foundation FWO Flanders (Brussels, Belgium).

\section{REFERENCES}

Barkema, H. W., Y. H. Schukken, T. J. Lam, M. L. Beiboer, H. Wilmink, G. Benedictus, and A. Brand. 1999. Management style and its association with bulk milk somatic cell count and incidence rate of clinical mastitis. J. Dairy Sci. 82:1655-1663.

Barrett, D. J., T. Clegg, A. M. Healy, and M. L. Doherty. 2006. A study of dry cow therapy and effects on SCC in 10 Irish dairy herds. J. Vet. Med. A Physiol. Pathol. Clin. Med. 53:140-144.

Blagitz, M. G., F. N. Souza, B. P. Santos, C. F. Batista, A. C. Parra, L. F. Azevedo, P. A. Melville, N. R. Benites, and A. M. Della Libera. 2013. Function of milk polymorphonuclear neutrophil leukocytes in bovine mammary glands infected with Corynebacterium bovis. J. Dairy Sci. 96:3750-3757.

Cameron, M., G. P. Keefe, J. P. Roy, I. R. Dohoo, K. A. MacDonald, and S. L. McKenna. 2013. Evaluation of a 3M Petrifilm on-farm culture system for the detection of intramammary infection at the end of lactation. Prev. Vet. Med. 111:1-9.

Cameron, M., G. P. Keefe, J. P. Roy, and K. A. MacDonald. 2011. Test characteristics of a petrifilm-based on-farm selective dry cow therapy system-Preliminary analyses. Pages $69-73$ in 3rd International Symposium on Mastitis and Milk Quality, St. Louis, MO. National Mastitis Council, http://nmconline.omnibooksonline $. \mathrm{com} /$.

Cameron, M., G. P. Keefe, J. P. Roy, H. Stryhn, I. R. Dohoo, and S. L. McKenna. 2015. Evaluation of selective dry cow treatment following on-farm culture: Milk yield and somatic cell count in the subsequent lactation. J. Dairy Sci. 98:2427-2436.

De Visscher, A., F. Haesebrouck, S. Piepers, W. Vanderhaeghen, K. Supré, F. Leroy, E. Van Coillie, and S. De Vliegher. 2013. Assessment of the suitability of mannitol salt agar for growing bovineassociated coagulase-negative staphylococci and its use under field conditions. Res. Vet. Sci. 95:347-351.

Dohoo, I. R., S. W. Martin, and H. Stryhn. 2003. Veterinary Epidemiologic Research. 2nd ed. VER Inc., Charlottetown, PEI, Canada.

Green, L. E., Y. H. Schukken, and M. J. Green. 2006. On distinguishing cause and consequence: Do high somatic cell counts lead to lower milk yield or does high milk yield lead to lower somatic cell count. Prev. Vet. Med. 76:74-89.

Halasa, T., K. Huijps, O. Østerås, and H. Hogeveen. 2007. Economic effects of bovine mastitis and mastitis management: A review. Vet. Q. 29:18-31.

Heikkilä, A. M., E. Liski, S. Pyörälä, and S. Taponen. 2018. Pathogen-specific production losses in bovine mastitis. J. Dairy Sci. 101:9493-9504.

Hiitiö, H., H. Simojoki, P. Kalmus, J. Holopainen, S. Pyörälä, and S. Taponen. 2016. The effect of sampling technique on PCRbased bacteriological results of bovine milk samples. J. Dairy Sci. 99:6532-6541.

Hogan, J. S., R. N. Gonzáles, R. J. Harmon, S. C. Nickerson, S. P. Oliver, J. W. Pankey, and K. L. Smith. 1999. Laboratory Handbook on Bovine Mastitis. Rev. ed. National Mastitis Council, Madison, WI.

Hubáčková, M., and D. Ryšánek. 2007. Effects of freezing milk samples on the recovery of alimentary pathogens and indicator microorganisms. Acta Vet. Brno 76:301-307.

Huxley, J. N., C. R. Helps, and A. J. Bradley. 2004. Identification of Corynebacterium bovis by endonuclease restriction analysis of the 16S rRNA gene sequence. J. Dairy Sci. 87:38-45.

Jashari, R., S. Piepers, and S. De Vliegher. 2016. Evaluation of the composite milk somatic cell count as a predictor of intramammary infection in dairy cattle. J. Dairy Sci. 99:9271-9286.

Laevens, H., H. Deluyker, Y. J. Schukken, L. De Meulemeester, R. Vandermeersch, E. De Muelenaere, and A. De Kruif. 1997. Influence of parity and stage of lactation on the somatic cell count in bacteriologically negative dairy cows. J. Dairy Sci. 80:3219-3226.

Madouasse, A., J. N. Huxley, W. J. Browne, A. J. Bradley, and M. J. Green. 2010. Somatic cell count dynamics in a large sample of dairy herds in England and Wales. Prev. Vet. Med. 96:56-64.

McDougall, S. 1998. Efficacy of two antibiotic treatments in curing clinical and subclinical mastitis in lactating dairy cows. N. Z. Vet. J. 46:226-232.

Osterås, O., and L. Sølverød. 2009. Norwegian mastitis control programme. Ir. Vet. J. 62:S26-S33.

Pantoja, J. C. F., C. Hulland, and P. L. Ruegg. 2009. Dynamics of somatic cell counts and intramammary infections across the dry period. Prev. Vet. Med. 90:43-54.

Piepers, S., G. Opsomer, H. W. Barkema, A. de Kruif, and S. De Vliegher. 2010. Heifers infected with coagulase-negative staphylococci in early lactation have fewer cases of clinical mastitis and higher milk production in their first lactation than noninfected heifers. J. Dairy Sci. 93:2014-2024.

Piepers, S., Y. H. Schukken, P. Passchyn, and S. De Vliegher. 2013. The effect of intramammary infection with coagulase-negative staphylococci in early lactating heifers on milk yield throughout first lactation revisited. J. Dairy Sci. 96:5095-5105.

Poutrel, B., and P. Rainard. 1981. California mastitis test guide of selective dry cow therapy. J. Dairy Sci. 64:241-248.

Pyörälä, S., and S. Taponen. 2009. Coagulase-negative staphylococciEmerging mastitis pathogens. Vet. Microbiol. 134:3-8. 
Rajala-Schultz, P. J., A. H. Torres, and F. J. Degraves. 2011. Milk yield and somatic cell count during the following lactation after selective treatment of cows at dry-off. J. Dairy Res. 78:489-499.

Scherpenzeel, C. G., I. E. den Uijl, G. van Schaik, R. G. Olde Riekerink, J. M. Keurentjes, and T. J. Lam. 2014. Evaluation of the use of dry cow antibiotics in low somatic cell count cows. J. Dairy Sci. 97:3606-3614.

Schukken, Y. H., R. N. González, L. L. Tikofsky, H. F. Schulte, C. G. Santisteban, F. L. Welcome, G. J. Bennett, M. J. Zurakowski, and R. N. Zadoks. 2009. CNS mastitis: Nothing to worry about? Vet. Microbiol. 134:9-14.

Schukken, Y. H., K. E. Leslie, A. J. Weersink, and S. W. Martin. 1992. Ontario bulk milk somatic cell count reduction program. 2. Dynamics of bulk milk somatic cell counts. J. Dairy Sci. 75:33593366.

Taponen, S., L. Salmikivi, H. Simojoki, M. T. Koskinen, and S. Pyörälä. 2009. Real-time polymerase chain reaction-based identification of bacteria in milk samples from bovine clinical mastitis with no growth in conventional culturing. J. Dairy Sci. 92:26102617.

Torres, A. H., P. J. Rajala-Schultz, and F. J. DeGraves. 2009. Diagnosis of intramammary infections at dry-off based on sampling strat- egy, epidemiology of pathogens, and agreement beyond chance. J. Vet. Diagn. Invest. 21:427-436.

Torres, A. H., P. J. Rajala-Schultz, F. J. Degraves, and K. H. Hoblet. 2008. Using dairy herd improvement records and clinical mastitis history to identify subclinical mastitis infections at dry-off. J. Dairy Res. 75:240-247.

Vanhoudt, A., K. van Hees-Huijps, A. T. M. van Knegsel, O. C. Sampimon, J. C. M. Vernooij, M. Nielen, and T. van Werven. 2018 Effects of reduced intramammary antimicrobial use during the dry period on udder health in Dutch dairy herds. J. Dairy Sci. 101:3248-3260.

Vasquez, A. K., D. V. Nydam, C. Foditsch, M. Wieland, R. Lynch, S. Eicker, and P. D. Virkler. 2018. Use of a culture-independent on-farm algorithm to guide the use of selective dry-cow antibiotic therapy. J. Dairy Sci. 101:5345-5361.

Wilson, D. J., R. N. Gonzalez, K. L. Case, L. L. Garrison, and Y. T. Groöhn. 1999. Comparison of seven antibiotic treatments with no treatment for bacteriological efficacy against bovine mastitis pathogens. J. Dairy Sci. 82:1664-1670.

Youden, W. J. 1950. Index for rating diagnostic tests. Cancer 3:32-35.

\section{APPENDIX}

Table A1. Sensitivity (Se), specificity (Sp), positive predictive value (PPV), and negative predictive value (NPV) with 95\% CI of 3 last composite milk SCC (SCC DHI-123) as a predictor of cows infected with one or more major pathogens at drying off (with bacteriological culturing serving as the gold standard) when the threshold was set at different sumSCC DHI-123 values (data set SCC DHI-123)

Cow infected with one or more major pathogens at drying off

\begin{tabular}{|c|c|c|c|c|c|c|c|c|c|c|}
\hline \multirow{2}{*}{ Stratum } & \multirow{2}{*}{$\begin{array}{l}\mathrm{n}, \\
\text { cows }\end{array}$} & \multirow{2}{*}{$\begin{array}{c}\text { sumSCC } \\
\text { DHI- } 123^{1} \\
(\times 1,000 \text { cells } / \mathrm{mL})\end{array}$} & \multirow{2}{*}{\multicolumn{2}{|c|}{$\mathrm{Se}$}} & \multirow{2}{*}{\multicolumn{2}{|c|}{$\mathrm{Sp}$}} & \multirow{2}{*}{\multicolumn{2}{|c|}{ PPV }} & & \\
\hline & & & & & & & & & \multicolumn{2}{|c|}{ NPV } \\
\hline \multirow{5}{*}{$\begin{array}{l}\text { Low-prevalence herd }{ }^{2} \\
\text { Heifers }\end{array}$} & & & & & & & & & & \\
\hline & 88 & $>50$ & $6: 8$ & $536-737$ & 420 & $325-532$ & 137 & $65-200$ & 80 ? & 827057 \\
\hline & & $\begin{array}{l}\geq 50 \\
\geq 100\end{array}$ & $\begin{array}{l}00.0 \\
63.6\end{array}$ & $\begin{array}{l}53.0-73.7 \\
53.6-73.7\end{array}$ & $\begin{array}{l}42.9 \\
72.7\end{array}$ & $\begin{array}{l}32.5-53.2 \\
63.4-82.0\end{array}$ & $\begin{array}{l}10.1 \\
25.0\end{array}$ & $\begin{array}{r}0.5-20.9 \\
16.0-34.0\end{array}$ & $\begin{array}{l}89.2 \\
93.3\end{array}$ & $\begin{array}{l}82.1-95.1 \\
88.1-98.5\end{array}$ \\
\hline & & $\geq 150$ & 63.6 & $53.6-73.7$ & 80.5 & $72.2-88.8$ & 31.8 & $22.1-41.5$ & 93.9 & $89.0-98.9$ \\
\hline & & $\geq 500$ & 27.3 & $18.0-36.6$ & 89.6 & $83.2-96.0$ & 27.3 & $18.0-36.6$ & 89.6 & $83.2-96.0$ \\
\hline \multirow[t]{6}{*}{ Multiparous cows } & 144 & & & & & & & & & \\
\hline & & $\geq 50$ & 94.3 & $90.5-98.1$ & 10.1 & $5.2-15.0$ & 25.2 & $18.1-32.3$ & 84.6 & $78.7-90.5$ \\
\hline & & $\geq 100$ & 82.9 & $76.7-89.0$ & 34.9 & $27.1-42.6$ & 29.0 & $21.6-36.4$ & 86.4 & $80.8-92.0$ \\
\hline & & $\geq 150$ & 68.6 & $61.0-76.2$ & 47.7 & $39.5-55.9$ & 29.6 & $22.2-37.1$ & 82.5 & $76.3-88.7$ \\
\hline & & $\geq 200$ & 57.1 & $49.1-65.2$ & 61.5 & $53.5-69.4$ & 32.3 & $24.6-39.9$ & 81.7 & $75.4-88.0$ \\
\hline & & $\geq 250$ & 48.6 & $40.4-56.7$ & 66.1 & $58.3-73.8$ & 31.5 & $23.9-39.1$ & 80.0 & $73.5-86.5$ \\
\hline \multirow{4}{*}{ Heifers } & & $\geq 150$ & 42.9 & $31.6-54.1$ & 62.7 & $51.7-73.7$ & 10.7 & $3.7-17.8$ & 91.3 & $84.9-97.7$ \\
\hline & & $\geq 200$ & 28.6 & $18.3-38.9$ & 71.6 & $61.4-81.9$ & 9.5 & $2.8-16.2$ & 90.6 & $83.9-97.2$ \\
\hline & & $\geq 250$ & 28.6 & $18.3-38.9$ & 79.1 & $69.8-88.4$ & 12.5 & $5.0-20.0$ & 91.4 & $85.0-97.8$ \\
\hline & & $\geq 500$ & 0.0 & $0.0-0.0$ & 89.6 & $82.6-96.5$ & 0.0 & $0.0-0.0$ & 89.6 & $82.6-96.5$ \\
\hline \multirow[t]{7}{*}{ Multiparous cows } & 127 & & & & & & & & & \\
\hline & & $\geq 50$ & 96.9 & $93.8-99.9$ & 7.4 & $2.8-11.9$ & 26.1 & $18.4-33.7$ & 87.5 & $81.7-93.3$ \\
\hline & & $\geq 100$ & 78.1 & $70.9-85.3$ & 28.4 & $20.6-36.3$ & 26.9 & $19.2-34.6$ & 79.4 & $72.4-86.4$ \\
\hline & & $\geq 150$ & 75.0 & $67.5-82.5$ & 45.3 & $36.6-53.9$ & 31.6 & $23.5-39.7$ & 84.3 & $78.0-90.6$ \\
\hline & & $\geq 200$ & 65.6 & $57.4-73.9$ & 56.8 & $48.2-65.5$ & 33.9 & $25.6-42.1$ & 83.1 & $76.6-89.6$ \\
\hline & & $\geq 250$ & 59.4 & $50.8-67.9$ & 66.3 & $58.1-74.5$ & 37.3 & $28.8-45.7$ & 82.9 & $76.3-89.4$ \\
\hline & & $\geq 500$ & 37.5 & $29.1-45.9$ & 88.4 & $82.9-94.0$ & 52.2 & $43.5-60.9$ & 80.8 & $73.9-87.6$ \\
\hline
\end{tabular}

${ }^{1}$ Sum of the number of times that SCC DHI-1, SCC DHI-2, and SCC DHI-3 exceeded the same threshold is $\geq 1$.

${ }^{2}$ The geometric mean SCC of all bulk milk SCC measurements per herd, calculated over a period of 6 mo before enrollment, was $<157,000$ cells/ $\mathrm{mL}$.

${ }^{3}$ The geometric mean SCC of all bulk milk SCC measurements per herd, calculated over a period of 6 mo before enrollment, was $\geq 157,000$ cells/ $\mathrm{mL}$. 